\section{A PROGRESS REPORT}

to

The Atomic Energy Commision

Washington, D. C. 20545

SPTII-LABELED MEMBRANES

subunițed by

Alec D. Kelth

Rerlod covered; September, 1973 to the present

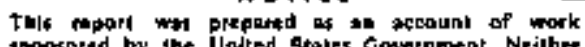
aponsopled by the Undted Staies Government. Nrilher the Unlied Siates sor the Undled Sintes ANomle Enargy

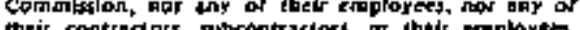
their contradors, subcontractor, or the if employtes,

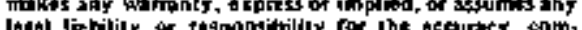

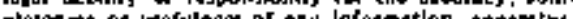

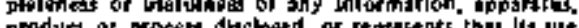

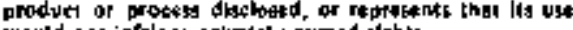
wauld not iafringte privalaly owned flghts.

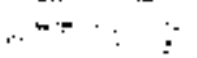

Blophyales Department

The Pennsylvanta State tniversity

Intversity Park, FA 16802 


\section{DISCLAIMER}

This report was prepared as an account of work sponsored by an agency of the United States Government. Neither the United States Government nor any agency Thereot, nor any of their employees, makes any warranty, express or implied, or assumes any legal liability or responsibility for the accuracy, completeness, or usefulness of any information, apparatus, product, or process disclosed, or represents that its use would not infringe privately owned rights. Reference herein to any specific commercial product, process, or service by trade name, trademark, manufacturer, or otherwise does not necessarily constitute or imply its endorsement, recommendation, or favoring by the United States Government or any agency thereof. The views and opinions of authors expressed herein do not necessarlly state or reflect those of the United States Government or any agency thereof. 


\section{DISCLAIMER}

Portions of this document may be illegible in electronic image products. Images are produced from the best available original document. 
ABSTRACT OF FROROSED WORK

The effects of membrane etructural perturbation induced by a nutber of semispherical nolecules will be investIgated. These investigations will concentrate op physiological processes which have a coincident detectable effect on the motion of apin labels. The interrelatlonship between membrane physical state and cytoplasmic viscosity will be investigated through the technique of using nickel as a paramggnetic line-broadening agent to subtract ESR signals outside membrane-bounded zones. The use and aynthes1s of ${ }^{15} \mathrm{~N}$ spin labels will be further developed and the general treatment of electron spin exchange and magnetic dipoie interactiong continue to be developed for the purpose of making aickel more useful and better understood as a line-broadening ageat. 
PROGRESS REPORT

\section{Nembrane structural perturbation:}

Eletr et a1. (ref. 42) turned out to be a central obaervation for a conslderable amount of research. They showed that Adamantane and aft are capable of disordering hydrocarbon domatns in membrane phospholipida. These perturb the temperature dependence of upin label motion, cell growth and oxygen uptake of whole cells. Thle general type of membrane effect will be further described in proposed work.

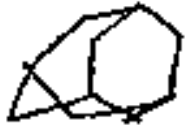

ADAMANTAKE

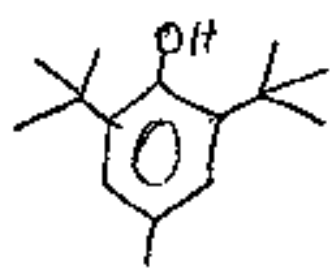

BHT

\section{Cytoplasmic viscostty*}

Ke1th and Snipee (ref.40) al 80 tuxned out to be an inportant research approach. Ao an Imediate follow-up to determine the average restriction to spin label motion imposed by the aqueous cytoplasn we carried out research on sarcoplasnic reticular vesiclea using spin labels that could be localized in and on the vesicle membranes (53). Appropriate electron microscopy was carried out which versfied that $\mathrm{NiCl}_{2}$ ueed in the experiments did not deform the vestcles. The general approach of ref. 40 was that $\mathrm{NiCl}_{2}$ broadened away nitroxide signals within about $15 \&$ spacing and that nickel is membrane Imperweable, therefore that nickel would subtract away nitroxide afgnala outside menbrane-bounded regtons but not Inside. Menbrane-permeable spin labels are then free to probe the bounded opace wthout an interfering bignal from outside the bounded region. Some cello and cellular preparations are deformed by the $\mathrm{NiCl}_{2}$ treatment and ve hape not yet learned how to prevent deformation to these preparations. Red blood cells are auch an example and, of course, we 
w11 not use guch samples that deform unt1l we have developed a means of preventing deformation.

Considerable research, usting this general capabitity of probing the viscosity of local zones is presently being undertaken and will be treated in proposed research.

\section{Phase transitions or temperature-dependence of physical state:}

In the past we have used spin-label motion as a parameter to correlate wth biological function to help make assignmentg of inferred phase transitions to physical state changes in the membrane 1lpids, References 44, 45, 51 and 55 were of thid general type where earlier observations were extended to other systems. Ref. 5j, however, shows an important novel aspect in addition. As squirrels of the San Bernardino Mountains of Southern California undergo hibernation and drop their body temperature to around $1^{\circ} \mathrm{C}$ there $1 \mathrm{~s}$ a simultaneour production of about $B$ mole percent of 1ygophosphatides in liver and heart tissue. Membrane preparations or phospholiptd extraces from theae t1save show no opin label-detectable phase transition whereas those from active aquirreila do. The additlon of lysophosphatidyl choline to the active phospholipid vestcles removes the transition in the same manner as that of the preparationg from the hibernating animale. Since the tissue preparatioas from hibernating animale have nuch more cold tolerance than do those from active aoimals these findinge are probably highly algalficant.

IV. 15 spin Iabelg: (47)

We embarked on research to develop ${ }^{15} \mathrm{~N}$ spin labels (ref. 47). We belleve that ${ }^{15}$ op sp labels have a good future; hotrever, the developrent of ouitable chemintry to syntheaize these spin. labels in good yleld from available precursore $t_{8}$ difficule. We can now synthesize plperidines in about 20\% yield and pyrrolidines in about 10\%, yleld. We are currentiy developing 
3

the requited chemistry to synthesize oxazolidines from available precursors.

Several (3-4) schemes exist in the literature for synthesizing 2-anino-2methylpropanol, the immediate precursor of oxazolidines by the Kana synthesis; however, when scaled down these procedures are not feasible, have very low yield or do not work at all. We are currently developing the scheme shown below and are trying to maximize yield on each step.

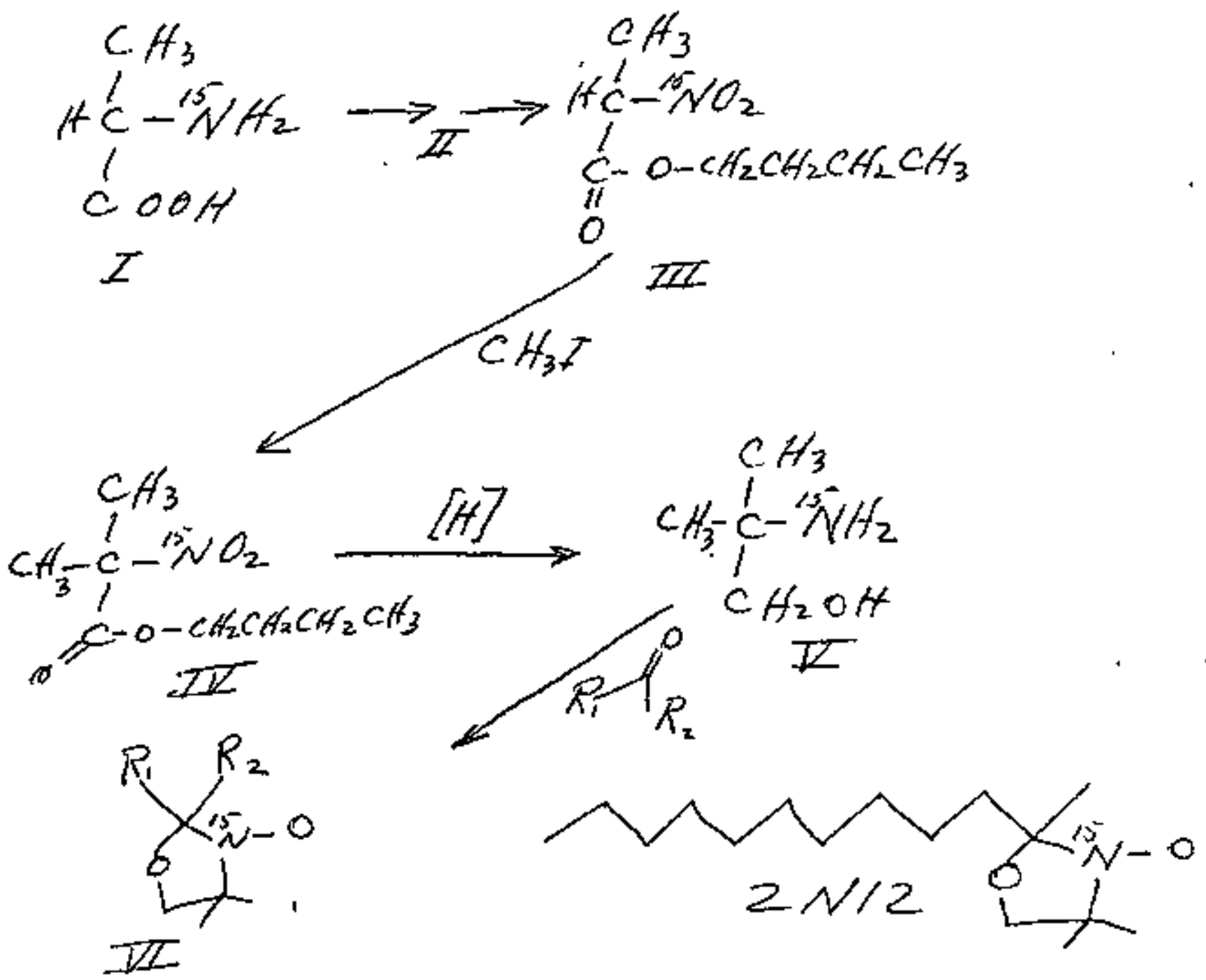

We believe we can get to ate V with $50 \%$ yield and then to step VI with $4 \%$ yield. This would yield 0.8 g of spin labeled 2 N12 for about $\$ 1000$ initial cost. Some compander bell ${ }^{14} \mathrm{~N}$ spin labels for $\$ 1 / \mathrm{mg}$; therefore, based on the is sale price the synthetic cost of $15_{\mathrm{W}}$ oxsezolidines is in 1 ind. 
v. other efforts

Some of the other references shown are carried ott in collaboration with Professor W. Snipes primarily in his laboratory, ace primarily supported by other eources, or are review articles requiring no primaxy research $(38,39,41,44,46,48,49,50$ and 52$)$. 
PUBLICATIONS:

33. Keith, A. D., B. J, Wisnieski, S. A. Henry and J, C. Willians. Membranes of yeasts, tn Lipids and Blowembranes of Eucaryotic Microorganism (ed. J. Erwin) Academic Fress, I973. pp. 259-321.

34. Keith, A. D., R. J. Mehlhorn, R. Freeman abd A. V. Nichols. Spin labeled lipid probes in serum 11poproteins. Chem. Phys. Lipids. 10: 223-236 (2973).

35. Williams, M. A., D. W. Taylor, J. Tinoco, M. A. Ojakian and A. D. Keith Utilization of $\mathrm{C}_{20}$-polyunsaturated fatty actd desaturase mitant. Blochem, Blophys. Res. Coum. $54: 1560-1566$ (1973).

36. Mehlhorn, R. J., W. Sntpes and A. D. Keith. Spln iabel motion in fatty acids. Blophys. J. 13:1223-1231 (1973).

37. Kefth, A. D., H. Sharnoff and G. E. Cohn. A sumary and evaluation of spin labels used for probes for btologleal membrane structure. BBA (Btomemb. Rev.) 300:379-419 (1973).

38. Torres-Pererta, J., R. Mehlhorn, A. D. Keith and I. Packer. Changes in membrane lipid atructure of 1lluminated chloroplasts - Scudies with spin-labeled and freeze-fractured nembranes. Arch. Blochen. Blophys, 160:90-99 (1974).

39. Cohn, G., A. D, KeIth and W. Sulpes, Spin-label translational diffugion In eolld tristearin. Blophys. J. 14:178-188 (1974).

40. Keith, A. D. and W. Sutpes. Viscosity of cellular protoplasm. Science $183: 666-667$ (1974).

41. Snipes, W., J. Cupp, J. Sands, A. Kelth and A. Davis, Calctum requirement for agsembly of the lipid-containing bacterlophage PM2. BBA (B1oment.) 339:311-322 (1974).

42. Eletr, S., M. A. Williams, T. Watk1ns and A. D. Ke1th. Perturbations of the dynamics of lipid alkyl chafng in membrane systers: Effect on the activity of membrane-bound enzynes. BBA 339:190-201 (1974).

43. Sulpes, W., J. Cupp, G. Cohn and A. Keith. ESR analysis of the nttroxide spin label tempone in aingle cryatals of the reduced tempone matrix. Biophys. J. 14:20-32 (1974).

44. Linden, C. D., A. D. Kelth and C. F. Fox, Correlations between fatty actd distribution in phospholiplds and the temperature dependence of membrane physical gtate. J. Supramol. Biol. 1:523-534 (1973).

45. Wade, N. L., R. W. Breldenbach, A. D. Keith and J. M. Lyons. Phase changes in castor bean mitochondrla. J. Plant Physiol, in press.

46. Kelth, A. D. and M. A. Hillams. Yeast lipd mutants: Isolation, ma1ntenance and spin label studies, in Methods in Enzynology. Academic Press, N.Y., In press.

47. Keth, A. D., D. Horvat and W. Snipes. Spectral characterization of N sp1n labels. Chem. Phys. Lipids, 1n press.

48. Snipes, W., A. Keith and P. Wanda. Active transport of choline by a, marine pseutononad. J. Bacter1ol, , in press.

49. Keith, A. B. Chemistry of fatty ac1ds. Enciclopedia della Chimica, Firenze, Italy. In press.

50. Keith, A. D., D. Deamer snd J. K. Raison. Functional aspects of the interrelationships between the Iipid and protein components of biological membranes. Science, in press.

51. Lyong, J. M., A. D. Ke1th and I, J, Thomason. Temperature Induced phaee tranaftions in nematode 1iplde and their influence on reepiration. In wanueript. 
Co0-2223-12 Eletx, Will lams, Watkins and Keith. Perturbations of the dynamics of Iipld alky1 chatns in membrane systems.

Coo-2223-10 Sntpes, Cupp, Cohn and Kelth. Blectron spin resonance-analysis of the nttroxide spin label $2,2,6,6$-tetramethylpiperidone-N-oxyl (TEMPONE) in single crystals of the reduced tempone matrix.

c00-2223-16 Snipes, Cupp, Sando, Keith and Davis. Calcium requirement for assembly of the lipid-containing bacteriophage PM2.

co0-2223-5 Meblhorn, Snipes and Kelth. Spin label motion in fatty acids. 600-2223-8. Ketth, Mehzhorn, Freeman and Nichols. Spin labeled 1ipid probes In serum 11poproteins:

c00-2223-6 Cohn, Keith and snipes. Spln label translational diffusion in solid trietearin.

Co0-2223-17 Snfpes and Keith. Viscosity of celluiar protoplanm.

co0-2223-13 Kelth, Sharnoff and cohn. A summary and evaluation of 6pin labele used a s probes for blological nembrane structures.

C00-2223-18. Preprint 